Олег Цевельов, кандидат наук з державного управління Національний університет оборони України імені Івана Черняховського, м. Київ ORCID ID 0000-0003-4549-5505 DOI: 10.33099/2617-1775/2020-02/316-324

\title{
СТАНДАРТИЗАЦІЯ ВІЙСЬКОВОЇ ОСВІТИ: ПІДХОДИ ТА ПРИНЦИПИ
}

У статті розглянуто теоретичні та практичні аспекти формування галузевої рамки кваліфікацій у галузі знань «Воєнні науки, національна безпека, безпека державного кордону», проаналізовано основні аспекти побудови Європейських рамок кваліфікацій та надано пропозиції щзодо уніфікаиії військової освіти.

Ключеві слова: військова освіти; Національна рамка кваліфікацій; галузева рамка кваліфікацій; компетенції; стандарти вищої освіти.

Постановка проблеми: Сучасна воєнна наука динамічно розвивається та швидко змінюється, охоплюючи різноманітні сфери та рівні суспільного життя. Масове використання, розробка та впровадження нових технічних засобів, гнучкі способи доступу до інформації та знань з використанням сучасних електронних пристроїв актуалізують необхідність підготовки висококваліфікованих військових кадрів.

Вимоги до якості підготовки майбутніх офіцерів швидко змінюються, разом 3 тим кваліфікація та рівень компетентностей випускників вищих військових навчальних закладів повинен відповідати сучасним підходам до будівництва та оснащення Збройних Сил та інших військових формувань, утворених відповідно до законодавства України. Тому проблема якісної професійної підготовки майбутніх офіцерів є актуальним завданням для усіх зацікавлених сторін (здобувачів вищої освіти, науково-педагогічних працівників, керівництва силових відомств).

Аналіз останніх досліджень i публікацій: Проблематиці розробки вітчизняної Національної та галузевої рамки кваліфікацій на основі європейського досвіду присвячені чисельні дослідження науковців України I.M. Алексєєва, О.Ю. Панфілова, Л.О. Петрової, І.В. Толока, І.Б. Гончаренка, Ю.О. Михайлова та інших. Питанням підвищення якості військової освіти на основі компетентнісно-орієнтованого стандарту присвячені такі дослідження науковців В.І. Лугового, Ю.І. Приходька, С.Я. Білявця, С.І. Брижатого, А.В. Балендра та інших.

У процесі розробки галузевої рамки кваліфікацій українські фахівці накопичили вагомий досвід та напрацювання щодо обгрунтування концептуальних засад створення даного нормативного документу та співставлення українських кваліфікацій з Свропейською рамкою кваліфікацій.

Водночас під час розробки галузевої рамки кваліфікацій у військовій галузі необхідно врахувати особливості української освітньої, соціальної, економічної та військової сфер, а також основні принципи Болонського процесу, важливим 
інструментом якого є Свропейська рамка кваліфікацій.

Метою статті $\epsilon$ аналіз основних проблем щодо розробки галузевої рамки кваліфікацій у галузі знань «Воєнні науки, національна безпека, безпека державного кордону» та iї відповідність вимогам і стандартам освіти Європейського та Євроатлантичного союзів, а також висвітлення ролі та місця галузевої рамки кваліфікацій у системі підготовки військовослужбовців Збройних Сил та інших військових формувань України.

Методи дослідження: системний аналіз і синтез, індукція і дедукція, порівняння, класифікація, узагальнення та систематизація.

\section{Виклад основного матеріалу.}

Сучасні тенденції розбудови системи військової освіти в Україні базуються на національних, європейських стандартах та рекомендаціях провідних країн-членів НАТО у військової освіти. Тісна взаємодія військової освіти 3 наукою, державною владою, військовим керівництвом та бізнесом $\epsilon$ необхідною умовою для забезпечення потреб суспільства та держави в військовому й технологічному розвитку. Тому важливим завданням для вищих військових навчальних закладів $є$ забезпечення відповідності українського стандарту вищої військової освіти вимогам сучасного захисту національним інтересам держави та визнаним світовим зразкам якісної фахової освітньопрофесійної підготовки майбутніх офіцерів.

Основні кваліфікації та стандарти вищої освіти на основі європейських та євроатлантичних вимог наведені та набули законної сили в Національній рамки кваліфікацій, яка затверджена постановою Кабінету Міністрів України № 1341 від 23 листопада 2011 року.

Національна рамка кваліфікацій визначає єдиний на національному рівні опис кваліфікаційних рівнів, через який усі кваліфікації та інші навчальні досягнення у сфері вищої освіти описані та співвіднесені між собою в узгоджений спосіб, та який визначає взаємозв'язки між кваліфікаціями вищої освіти [1].

Одними 3 найважливіших заходів у країнах європейського освітнього простору, спрямованих на впровадження Національної рамки кваліфікацій та компетентністного підходу до опису кваліфікацій на галузевому рівні, $\epsilon$ розроблення галузевих рамок кваліфікацій. На сьогодні в європейських країнахчленах НАТО існують два основні підходи до розроблення галузевих рамок кваліфікацій: перше - для галузей освіти; друге - для галузей (секторів) ринку праці (секторальні рамки кваліфікації). Галузеві рамки кваліфікацій, які розробляються у сфері освіти, мають визначати загальні для певної галузі освіти вимоги до результатів навчання та бути орієнтиром для створення стандартів вищої освіти. На відміну від стандартів вищої освіти, які мають бути розробленими в межах певних спеціальностей, галузеві рамки кваліфікацій мають надавати узагальнений опис кваліфікацій, які можуть здобуватись за різними освітніми програмами в межах кожної із спеціальностей певної галузі освіти.

Галузева рамка кваліфікації повинна спиратися на вимоги Національної рамки кваліфікації та більш широко деталізувати основні компетенції, що 
потребують певних знань і умінь від слухачів.

У національній системі вищої освіти Національна рамка кваліфікацій виконує наступні функції:

- сприяє прозорості та розумінню кваліфікацій, дає чіткий опис відповідних їм результатів навчання та роз'яснення притаманних прав на професійну діяльність і пов’язане з цим визнання;

- окреслює точки інтеграції між різними кваліфікаціями та типами кваліфікацій, співвіднесення одних кваліфікацій з іншими та ілюструє можливі траєкторії навчання;

- відображає узгодженість спеціалізацій на національному рівні;

- запроваджує загальні принципи перегляду та удосконалення існуючих та розроблення нових кваліфікацій.

Національна рамка кваліфікацій $є$ важливою частиною академічної архітектури, яка сприяє підтримці та розвитку вищих навчальних закладів. Вищі навчальні заклади мають забезпечувати чіткі параметри для розроблення та валідації кваліфікацій, які вони присвоюють. Вони мають демонструвати, що кожна кваліфікація, яку вони присвоюють, позиціонується на відповідному рівні Національної та галузевої рамки кваліфікацій.

Галузева рамка кваліфікацій $є$ складовою системи професійних кваліфікацій, має узгоджуватися із Національною рамкою кваліфікацій i $\epsilon$ інструментом розроблення, ідентифікації, співвіднесення та визнання кваліфікацій у визначеній галузі знань. Вона розробляється за певним видом (видами) економічної діяльності чи спорідненої діяльності державної служби до якої, як спеціальний від державної служби відноситься й військова служба.

Як зазначає науковець А. Балендр на відміну від Національної рамки кваліфікацій, галузева рамка кваліфікацій охоплюють усі освітні кваліфікації, якими визначено, що слухачі можуть знати, розуміти і вміти робити на основі отриманої кваліфікації (результатів навчання), а також яким чином мають бути сформовані кваліфікації [2, с.35].

Водночас, галузева рамка кваліфікацій повинна надавати опис професійних характеристик які базуються на описі відповідних рівнів у Національної рамці кваліфікацій на основі дескрипторів: - знання; - уміння та інтегральні компетенції/компетентності. Для кожного рівня знань необхідно вказати загальні компетентності за професійними напрямами, освітні вимоги до здобувача відповідної професійної кваліфікації, вказати на якій підставі може бути прийняте рішення про присвоєння відповідної професійної кваліфікації, назва документу (сертифікату), вказані академічні та професійні права здобувача.

За результатами аналізу досліджень галузевих рамок кваліфікації Європейських країн зроблено висновки, що окремі європейські галузеві рамки кваліфікацій: по суті, є каталогами детальних описів кваліфікацій, що дозволяють виробляти оцінювання та сертифікацію фахівців; містять рамки опису кваліфікацій спеціалістів і насамперед призначені для використання вирішення завдань ринку праці. Такі рамки кваліфікацій є орієнтирами, які дозволяють представити результати навчання в термінах, зрозумілих 
роботодавцям, характеристиках успішного виконання завдань в контексті виробництва чи виконання відповідних завдань [3, с.201-206].

Необхідно відзначити, що розробка галузевої рамки кваліфікації $\epsilon$ ресурсовитратним і тривалим процесом, що вимагає узгоджених дій усіх зацікавлених сторін. Під час розробки галузевої рамки у галузі наук «Воєнні науки, національна безпека, безпека державного кордону» потрібно узгодити загальні компетенції та стандарти між всіма складовими сектору безпеки i оборони, які готуються та залучаються до оборони територіальної цілісності держави та участі у відбитті збройної агресії.

Поряд 3 цим варто зауважити, що наразі понятійний апарат і термінологія у законодавстві та нормативно-правовій базі, що стосується питань стандартизації військової освіти, значно різняться, тому виникає необхідність опрацювання єдиної термінології для проекту розробки галузевої рамки кваліфікацій у галузі знань «Воєнні науки, національна безпека, безпека державного кордону» [4].

Одним 3 ключових елементів професійної підготовки майбутніх офіцерів для всіх силових відомств є дисципліни циклу професійної та практичної підготовки фахівців та професіоналів у визначеній галузі знань. Тобто, актуальним $є$ перегляд переліку дисциплін циклу професійної підготовки, а також оновлення робочих навчальних освітніх програм дисциплін цього переліку з урахуванням розробки галузевої рамки кваліфікацій для бакалаврів та магістрів в новому компетентнісно-орієнтованому стандарті. Згаданий перегляд переліку дисциплін здійснювався 3 урахуванням національного законодавства та накопичувального досвіду військової освіти. Іншою, не менш важливою задачею $є$ формування співвідношень дисциплін та переліку компетентностей відповідно до спеціальностей у військовій сфері.

Галузева рамка кваліфікацій у галузі знань «Воєнні науки, національна безпека, безпека державного кордону» повинна, 3 одного боку, співставити результати навчання військовослужбовців Збройних Сил та інших військових формувань, утворених відповідно до законодавства України, а з іншого боку, зберегти індивідуальні особливості національних систем військової освіти та інституційних засад військової служби. Однією 3 таких індивідуальних особливостей української системи військової освіти в даній галузі знань, яку, на нашу думку, варто зберегти, є високий рівень загальновійськової підготовки майбутніх офіцерів. Узагальнений перелік компетенцій загальновійськової підготовки доцільно внести до галузевої рамки у вигляді компетентностей для всіх військових формувань та правоохоронних органів, які мають ознаки військових формувань.

Набуття компетентностей, як результатів навчання, передбачається в межах засвоєння дисциплін, перелік яких узгоджений з переліками дисциплін провідних світових зразків стандартів освітньо-професійної підготовки офіцерських кадрів. Такі заходи сприяють підвищенню якості підготовки майбутніх офіцерів 3 метою досягнення відповідності рівня компетентностей вимогам сучасних Збройних Сил та світовим стандартам. Таким чином, впровадження галузевої рамки кваліфікацій передбачає оновлення освітніх 
стандартів, освітніх програм, навчальних планів та відповідних робочих програм. Таким чином галузева рамка кваліфікацій складається 3 кваліфікаційних рівнів, які описуються в термінах компетентностей і за якими розподіляються всі професійні кваліфікації певного виду (видів) економічної чи державної діяльності. Кваліфікаційний рівень галузевої рамки кваліфікацій визначається через узагальнений опис змісту, складності та обсягу компетентностей, які особа має засвоїти та продемонструвати для здобуття кваліфікацій цього рівня.

Поняття «кваліфікація» визначається українським законодавством як «визнана уповноваженим суб'єктом та засвідчена відповідним документом стандартизована сукупність здобутих особою компетентностей (результатів навчання)». Таке визначення в основному відповідає тому, як розуміється поняття «кваліфікація» у міжнародних документах Європейського Союзу. Проте, за самим цим поняттям стоїть значно глибша соціальна реальність. 3 одного боку, кваліфікації повинні відповідати потребам військової служби, оскільки без цього неможливе створення професійної армії. 3 іншого боку, наявність у людини відповідної кваліфікації робить іï більш затребуваною на ринку праці і, відповідно, більш захищеною, коли вона проходить службу чи продовжує свою працю після звільнення. Кваліфікація - це те, що потребує інвестицій, як суспільних, так і особистих. На загальнонаціональному рівні такою інвестицією має стати створення національної системи кваліфікацій, яка має забезпечити ефективне формування, оцінювання та визнання кваліфікацій військової освіти [5].

На сьогодні експерти дійшли згоди щодо необхідності розділяти два види кваліфікацій - освітні (академічні) та професійні. Відповідно до вимог статті 34 Закону України «Про освіту» визначається: що «освітня кваліфікація - це визнана закладом освіти чи іншим уповноваженим суб’єктом освітньої діяльності та засвідчена відповідним документом про освіту сукупність встановлених стандартом освіти та здобутих особою результатів навчання (компетентностей).

Професійна кваліфікація - це визнана кваліфікаційним центром, суб'єктом освітньої діяльності, іншим уповноваженим суб’єктом та засвідчена відповідним документом стандартизована сукупність здобутих особою компетентностей (результатів навчання), що дозволяють виконувати певний вид роботи або здійснювати професійну діяльність» [6].

Виходячи 3 цього, і освітню, i професійну кваліфікацію слід вважати сукупністю компетентностей або результатів навчання. Одним із завдань галузевої рамки кваліфікацій є забезпечення відповідності між освітніми та професійними кваліфікаціями, а також їх відповідності потребам військової служби, створення ефективних механізмів визнання кваліфікацій, які здобуваються людиною протягом періоду проходження військової служби.

Стандарти вищої освіти за кожною спеціалізацією розробляє центральний орган виконавчої влади у сфері освіти і науки з урахуванням пропозицій галузевих державних органів, до сфери управління яких належать заклади вищої освіти, і галузевих об'єднань організацій роботодавців та затверджує їх 
за погодженням із Національним агентством із забезпечення якості вищої освіти. Нові стандарти вищої освіти є наступним поколінням стандартів i замінюють собою Галузеві стандарти вищої освіти (ГСВО), які розроблялись у 2002-2014 роках відповідно до законодавства. Стандарти базуються на компетентному підході і поділяють філософію визначення вимог до фахівця, закладену в основу Болонського процесу та в міжнародному Проекті Європейської Комісії «Гармонізація освітніх структур в Європі» (Tuning Educational Structures in Europe, TUNING).

Уніфікація військової освіти, особливо на оперативному та стратегічному рівнях, повинна створити умови для поєднання стандартів підготовки офіцерських кадрів Збройних Сил та інших військових формувань, утворених відповідно до законів України. Така підготовка повинна проводитися на базі одного навчального центру (наприклад, НУОУ) за відповідною єдиною програмою для всіх офіцерських кадрів сектору оборони, що розглядаються або прагнуть бути керівниками оперативного та стратегічного рівнів. Це надасть позитивні результати у порядку спільних підходів до розуміння організації оборони держави та їі захисту. 3 метою уніфікації та вдосконалення військової освіти: по-перше необхідно визначитися із складовими сил безпеки й оборони, ролі та місця кожного військового формування у системі захисту держави в умовах воєнних загроз та під час участі у спільних операціях; по-друге - чітко визначитися із військовими формуваннями та по-трете - компетентності, стандарти й необхідний об'єм знань для отримання первинного офіцерського звання та готовності до управління військовим підрозділом Збройних Сил чи іншого військового формування України у різних умовах ведення бойових дій. Таким чином підготовка офіцерів для Збройних Сил та інших утворених відповідно до законів України військових формувань повинна проводитися у строгій відповідності до розроблених і затверджених стандартів вищої освіти 3 воєнних дисциплін. Офіцери повинні знати тактику дій, планування бою та вміти управляти військовими підрозділами в ході бойових дій, виконувати відповідні завдання із захисту держави та їі територіальній цілісності.

Водночас, підготовка за спеціальностями враховуючи специфіку інших військових формувань повинна проводитися в комплексі основних стандартів й програм навчання офіцерів тактичної ланки. Для уніфікації військової освіти та створення галузевої рамки кваліфікації у галузі знань «Воєнні науки, національна безпека, безпека державного кордону» існує ряд проблем, які необхідно вирішувати як на законодавчому рівні, так й під час формування єдиних стандартів військової освіти на всіх рівнях.

Висновки та перспективи подальших наукових досліджень: Військова служба вимагає щоденного виконання професійних обов'язків, вирішуючи питання забезпечення захисту територіальної цілісності держави, ii національної безпеки, дотримання прав людини, використання правил ведення війни тощо. Тому об'єктивною є потреба у гармонізацій системи підготовки сектору безпеки і оборони для виконання спільних завдань як в мирний час, так й в період воєнного стану. Саме тому, актуальною постає роль галузевої рамки кваліфікацій в системі підготовки фахівців у галузі військової освіти, яка 
виступає інструментом забезпечення прозорості, гнучкості та мобільності курсантів і може слугувати засобом інтерпретації кваліфікацій та вирішувати проблему систематичного узгодження кваліфікацій.

Запровадження галузевої рамки кваліфікацій у систему підготовки військовослужбовців сектору безпеки i оборони на національному рівні, забезпечує не тільки чітку структурованість, можливість застосування високоефективних практик країн Свропейського та Євроатлантичного союзів, а також значне посилює стандарти національної безпеки, сприяє підвищенню обороноздатності країни й узгодженості дій всіх елементів сектору безпеки i оборони.

Водночас, потребує подальше вивчення досвіду передових країн ЄС та НАТО у питаннях розробки та впровадження галузевої рамки кваліфікацій, що вимагає грунтовного дослідження окресленого напряму.

\section{ЛІТЕРАТУРА}

1. Постанова Кабінету Міністрів України №1341 «Про затвердження Національної рамки кваліфікацій» від 23 листопада 2011 р. [Електронний ресурс]. - Режим доступу: http://zakon3.rada.gov.ua/laws/show/1341-2011-п.

2. А. Балендр. Роль та місце галузевої рамки кваліфікацій у системі підготовки прикордонників країн Свропейського союзу // Збірник наукових праць Національної академії Державної прикордонної служби, серія: педагогічні науки № 2(9) - 2017 р. С. - 30-40.

3. I. Алексєєва. Свропейські рамки кваліфікацій - опорна конструкція інтеграції національних систем освіти // Актуальні питання фармацевтичної і медичної науки та практики. - 2017. - Т. 10, №2(24) - С. 201-206.

4. Постанова Кабінету Міністрів України №1410 «Про створення єдиної системи військової освіти» від 15 грудня 1997 року зі змінами № 1170 від 26 вересня 2007 року [Електронний ресурс]. Режим доступу : https://zakon.rada.gov.ua/laws/show/1410-97-\%D0\%BF.

5. Закон України №1556-VII «Про вищу освіту» від 1 липня 2014 р. [Електронний ресурс]. - Режим доступу : http://zakon4.rada.gov.ua/laws/show/155618/page2.

6. Закон України від 05.09.2017 р. «Про освіту» - [Електронний ресурс]. - Режим доступу: http://zakon5.rada.gov.ua/laws/show/2145-19.

7. Постанова Кабінету Міністрів України від 29.04.2015 р. № 266 «Про затвердження переліку галузей знань і спеціальностей, за якими здійснюється підготовка здобувачів вищої освіти» - [Електронний режим]. - Режим доступу : http://zakon4.rada.gov.ua/laws/show/2662015-П.

\section{REFERENCES}

1. Postanova Kabinety Ministriv Ukrainu №1341 "Pro zatverdjenna Nastionalnoi ramku kvalifikastii” vid 23 listopada 2011 r. [Electronyi resyrs]. - Rejum dostypy : http://zakon3.rada.gov.ua/laws/show/1341-2011-п.

2. A. Balendr. Rol ta micto galuzevoi ramku kvalifikatsii u sistemi pidgotovku prikordonikiv krain Evropeiskogo soyzy // Zbornik naykovuh prats Nashionsl akedemic bjder gads, series: pedagogihni nayki № 2(9) - 2017 r. C. - 30-40.

3. I. Alekseeva. Europian ramki kvalifikatsii - oporna konstryktsia integratsii nathionaliti system osvitu // Aktualni putana farmatseptichnoi I meduchnoi nayki ta praktuki. - 2017. -T.10, №2(24) - C. 201-206.

4. Postanova Kabinety Ministriv Ukrainu №1410 "Pro stvorenna edinoi sistemu viiskovoi osvitu” vid 15 grydna 1997 roky zi zminami № 1170 vid 26 veresna 2007 roky [Electronyi resyrs]. 
- Rejum dostypy : https://zakon.rada.gov.ua/laws/show/1410-97-\%D0\%BF.

5. Zakon Ukrainu №1556-VII "Pro vushy osvity" vid 1 lupna 2014 r. [Electronyi resyrs]. Rejum dostypy : http://zakon4.rada.gov.ua/laws/show/1556-18/page2.

6. Zakon Ukrainu "Pro osvity" vid 05.09.2017 r. - [Electronyi resyrs]. - Rejum dostypy : http://zakon5.rada.gov.ua/laws/show/2145-19.

7. Postanova Kabinety Ministriv Ukrainu vid 29.04.2015 r. № 266 "Pro zatverdgenia pereliku galuzei znania I cpetsialnostei, za iakumu zdisnuetsia pidgotovka zdobuvachiv vushoi osvitu" [Electronyi resyrs]. - Rejum dostypy : http://zakon4.rada.gov.ua/laws/show/266-2015-ח.

\section{РЕЗЮМЕ}

Олег Цевелев,

кандидат наук с государственного управления Национальный университет обороны Украины имени Ивана Черняховского

\section{Стандартизация военного образования: подходы и принципы}

В статье рассмотрено теоретические и практические аспекты форрмирования отраслевой рамки квалификаций в отрасли знаний «Военные науки, национальная безопасность, безопасность государственной граниџы», проанализировано основные аспекты построения Европейских рамок квалификаций и представлены предложения по унификации военной науки.

Ключевые слова: военная наука; Национальная рамка квалификаций; отраслевая рамка квалификаций; компетенции; стандарты высшего образования.

\section{SUMMARY}

Oleg Tsevelyov, candidate of sciences in public administration

National Defence University of Ukraine named after Ivan Cherniakhovskyi

\section{Standardization of military education: approaches and principles}

Introduction. The article considers the theoretical and practical aspects of the formation of the sectoral qualifications framework in the field of knowledge "Military Sciences, National Security, State Border Security", analyzes the main aspects of building the European Qualifications Framework and provides proposals for unification of military education.

Purpose. Requirements for the quality of training of future officers are changing rapidly, however, the qualifications and level of competencies of graduates of higher military educational institutions must meet modern approaches to building and equipping the Armed Forces and other military formations formed in accordance with Ukrainian legislation. Therefore, the problem of quality training of future officers is an urgent task for all stakeholders (applicants for higher education, research and teaching staff, management of law enforcement agencies).

Methods. System analysis and synthesis, induction and deduction, comparison, classification, generalization and systematization.

Results. In the process of developing the sectoral qualifications framework, Ukrainian specialists have accumulated significant experience and experience in substantiating the conceptual basis for the creation of this normative document and comparing Ukrainian qualifications with the European Qualifications Framework.

At the same time, when developing the sectoral qualifications framework in the military field, it is necessary to take into account the peculiarities of the Ukrainian educational, social, economic 
and military spheres, as well as the basic principles of the Bologna Process, an important tool of which is the European Qualifications Framework.

Originality. Analysis of the main problems in the development of the sectoral qualifications framework in the field of knowledge "Military Sciences, National Security, State Border Security" and its compliance with the requirements and educational standards of the European and EuroAtlantic alliances, as well as highlighting the role and place of the sectoral qualifications framework. other military formations of Ukraine.

Conclusion. The introduction of a sectoral qualifications framework in the training of security and defense personnel at the national level provides not only a clear structure, the ability to apply highly effective practices of the European and Euro-Atlantic alliances, but also significantly strengthens national security standards, enhances national defense and coherence security and defense.

Key words: Military education; National Qualifications Framework; sectoral qualifications framework; competencies; higher education standards. 